\title{
Reforms of Tax System in Vietnam in Response to International Integration Commitments until 2020
}

\author{
SU DINH THANH \\ University of Economics - HCMC - dinhthanh@ueh.edu.vn \\ BUI THANH TRUNG \\ University of Economics - HCMC - trungbt@ueh.edu.vn \\ TRAN TRUNG KIEN \\ University of Economics - HCMC - kientt@ueh.edu.vn
}

\section{ARTICLE INFO ABSTRACT}

Article history:

Received:

Aug. 272014

Received in revised form:

Jan. 302015

Accepted:

Mar. 262015

Keywords:

tax reform, international integration, tax competition, tax harmonization.
Vietnam's taxation system has undergone fundamental reforms since the 1990s. Tax reform program of the 2000-2010 period was conducted successfully, putting in place a tax system appropriate to the market economy and necessary legal conditions for accession to the World Trade Organization and international integration. After over 20 years of tax reform, taxation capacity has been improved; raising tax revenue is comparable to economic and structural potentials of tax system. The Vietnamese Prime Minister ratified a tax system reform strategy for 2010-2020 with ambitious target of tax revenue at $23-24 \%$ of GDP. The present study finds that raising tax revenue size is of no benefit to economic growth. Therefore, by 2020 , Vietnam will have overcome several challenges in the process of tax reform such as broadening the tax base, simplifying the tax administration according to international standards, and harmonizing tax system grounds between ASEAN members. 


\section{Introduction}

Tax reform are changes from the existing tax structure toward a more optimal one. Tax reform must take the existing tax system as its starting point and accept the fact that actual changes are slow and piecemeal. There are major changes in tax systems of many countries over the last three decades. The underlying motivation varies between countries. The philosophy of reforms changes as role of the state changes. The most important reason for recent tax reforms in many developing countries is to evolve a tax system that meets requirements posed by international integration.

Vietnam's taxation system has undergone fundamental reforms since the 1990s. Tax reform program of the 2000-2010 period is carried out successfully, thereby developing a tax system that supports a market economy and the WTO accession. Tax structure has been modernized, moving from taxing high-income earners to a more universal personal income tax and adopting a natural resource tax law to efficiently use natural resources. Tax policy has taken account of emerging trends to improve tax compliance of the rapidly growing private sector. Tax revenue in the period 2006-2010 accounted for 23\% of GDP, a twofold increase compared with that of the previous five-year period. The average annual growth rate of tax revenue was $19.6 \%$ during the period. Decision 732/2011/QD-TTg ratified by Vietnamese Prime Minister set up a tax system reform strategy for 2010-2020 with ambitious target of tax revenue of 23-24\% of GDP. Raising revenue is probably much more difficult due to limited revenue sources and economic stagnancy.

With the change in the development strategy in favor of market-determined resource allocation, the conventional approach of raising tax revenue to finance a large public expenditure without much consideration for economic effects has been given up (Rao, 2000). The recent approaches to tax reform emphasize on minimizing distortions in tax policy to maintain the competitiveness of the economy. It is not clear what major challenges the Vietnam's tax system faces. The present study is designed to assess the evolution of tax system with regard to the systemic reforms in the design and operation of the taxes. First, it discusses the directions and the principles which have formed the basis of Vietnam's tax systemic reforms as well as determinants of taxation capacity, and next comes the analysis of challenges of Vietnam's tax system in the context of international integration, including relationships between tax and growth, tax administration and tax harmonization in the ASEAN region. 
This paper comprises the following sections. After this introduction, Section 2 summarizes relevant materials including an assessment of the tax competition and tax harmonization theory, theories of tax reform, and several empirical studies. Section 3 illustrates current state of the Vietnam tax system. Section 4 discusses major challenges of the Vietnam tax reform. Finally, Section 5 presents some conclusions and recommendations.

\section{Literature review}

\subsection{Taxation theories and models of tax reform}

Tax reforms are changes from the existing tax system to an optimal one that helps facilitate economic development. When the role of the government changes, model of tax reforms also changes. Historically, there are at least three different tax reform models: (i) the optimal tax model; (ii) the Harberger tax model; and (iii) the supply-side tax model.

\subsubsection{The optimal tax model (OT)}

The theory of optimal taxation pioneered by Diamond and Mirrlees (1971) suggests that besides financing government expenditures, the other three main objectives of the tax systems are efficiency, equity, and simplicity (Warburton \& Hendy, 2006). As regards the efficiency, the Production Efficiency Theorem proposed by Diamond and Mirrlees (1971) emphasizes that taxes on intermediate goods and international trade are inappropriate because of their price distortions. Taxation equity can also be met if income or consumption taxes do not produce resource misallocations. The optimal tax system should be levied on income. Ideally, a national personal income tax should have progressive rates, include capital gains in the tax base, and be integrated with the corporate income tax so that both the decision to incorporate and the choice between debt and equity finance are more neutral (Auerbach, 2010).

However the optimal tax model has not been useful as a practical guide (Rao, 2000) because of the trade-off between efficiency and equity in tax policy, and high cost of information and administration of designing an optimal tax model (Ahmad \& Stern, 1991). Regarding imperfectly competitive market, information cost and uncertainty, optimal tax theory has been modified by relaxing some of its assumptions. 


\subsubsection{The Harberger tax model}

Like the OT model, the Harberger tax (HT) model (Harberger, 1962) is well grounded in theory but is not aimed at designing an optimal tax system. The remarkable point of this model is its emphasis on best practices and balance between efficiency, distribution and administrative capability. Therefore, policy makers should focus on best practice experiences to minimize tax-induced distortions and improve the feasibility of tax administration and attempt to discourage tax avoidance and evasion. Tax reforms need to be established to minimize taxpayers' compliance costs and government's administrative cost (Tanzi, 2008). The HT reform for developing countries is suggested by a uniform tariff and a broad-based value-added tax (Rao, 2000). GATT and the WTO are basic reasons for reforming VAT tariffs in many signatory countries. Consequently, VAT becomes more important in many countries.

\subsubsection{The supply-side tax model}

The supply-side tax (SST) model emphasizes reduction in the government's role, or the size of public expenditures, by tax cuts, particularly the direct taxes to minimize disincentives to saving and investment (Rao, 2000). Therefore, tax reform should minimize exemptions to broaden the tax base and emphasize less rate differentiation to minimize price distortions.

\subsubsection{Recent tax model}

As an attempt to make the tax systems simple and transparent, the recent tax reform links core contents of the three above-mentioned models. Main concerns such as administrative, political, and information constraints in designing and implementing tax reform policy are taken into consideration. Therefore, proposal of a good tax policy includes a broader tax base that helps ensure horizontal equity, reduce administrative costs, and lower tax rates and differentiation, thereby improving tax compliance and motive for saving and investment. Emphasis on horizontal equity also implies strengthening administration and enforcement of the tax and the development of proper information systems and automation (Rao, 2000; Mirrlees et al., 2012).

\subsection{Tax competition and tax harmonization}

International economic integration enhances capital mobility. Tax competition, a situation in which taxpayers take advantage of tax differentials between countries to reduce the tax burden, would lead to a lower tax revenue and suboptimal levels of public 
expenditures. On the one hand, tax competition has many positive impacts. People can keep a larger portion of their income due to lower tax burdens, which improves saving, consumption, and investment (Mitchell, 2009). Tax competition also promotes economic liberalization and a good tax policy in many countries. Investors have strong incentives to go against corruption to increase their profit. A simple tax system attracts labor and capital.

On the other hand, tax competition may hinder economic performance. With reference to interregional trade and tax competition, Wilson (1987) argues that capital taxation causes an inefficient distribution of public good outputs across regions, which is accompanied by an inefficient pattern of trade. Tax competition among countries leads to a race of tax reduction and shrinkage of tax revenue as empirical evidence of EU (Bovenberg, Cnossen \& Mooij, 2003, Mendoza \& Tesar, 2005). Tax competition also reduces the efficiency of capital allocation by shifting tax burden onto less mobile factors such as labor, undermines democracy, and increases complexity of the tax system by forcing governments into continuously modifying tax systems (Mitchell, 2009).

The pitfalls of tax competition could be solved by coordination between countries in setting similar or identical tax rates that are applicable to every taxpayer - a situation referred to as tax harmonization. In the EU, tax harmonization is already achieved with fuel, alcohol, and tobacco while a great effort is made for personal and corporate income taxes (Mitchell, 2009). Moreover, tax harmonization can also refer to the coordination between member states in avoiding any national tax measures that lead to the malfunction of the market. Arguably, strict supranational taxation is necessary to harmonize tax rates and guarantee adequate supply of public goods.

\subsection{Empirical studies review}

There have been changes in tax systems in several countries over the last three decades. One of the most important reasons for tax reforms in developing economies is to develop a tax system that meets requirements of a market economy and ensures international competitiveness (Rao, 2000). A country with a higher income level, lower population growth rate, wider trade openness, lower agricultural share in GDP, and higher institutional quality is likely to have a higher taxation capacity (Le, MorenoDodson \& Rojchaichaninthorn, 2008; Bird \& Gendron, 2007). Le et al. (2008) emphasize that developing countries have difficulties in expanding the scope for taxation efficiently and equitably, which is in turn dependent on the taxable capacity. These 
countries, therefore, should adopt a long-term vision for tax reforms and specific strategies for reforms cannot be "one size fits all".

Discussions about recent tax reforms in Thailand and Indonesia show that an efficient and effective tax structure and administration are crucial to the fiscal sustainability and economic development (Sujjapongse, 2005; Ikhsan, Trialdi \& Syahrial, 2005). The Thai government has introduced numerous initiatives such as e-revenue, e-excise, and ecustoms to facilitate tax collection and reduce tax evasion and corruption. The Indonesian government has adopted a plan to increase its tax revenue by improving tax administration and the tax base. Rao (2005) shows that the reforms should focus on improving tax revenue while minimizing price distortions. The tax administration reforms promise to increase revenues and provide the elbow room necessary for calibrating future reforms. Both the political economy factors and the administrative factors are considered as causes for the unsuccessful implementation of tax reforms.

Moreover, the declining pressures on corporate tax due to increasing international integration emphasize the significance of VAT (Kim, 2005). By examining the effects of switching from a dual tax system to a unified system, Lin (2004) emphasizes that a decrease in the tax rate on domestic capital has no effect on the domestic interest rate, capital-labor ratio, or output-labor ratio, but it increases domestic capital, decreases foreign capital, and increases trade surplus.

In their study of Chinese tax reform, Brys, Matthews, Herd, and Wang (2013) suggest that a country's culture, traditions, and legal system play an important part in shaping its tax regime, the Chinese government should develop a more growth-friendly, simple, and transparent tax system. Another research shows an ample margin for higher tax levels in Asia, except for Japan and Korea, especially personal income tax (Martinez-Vazquez, 2011). The higher tax pressure could also come from providing a wider role for VAT and a diminishing role for customs duties. Suzuki (2014) finds that effective tax rates in small countries are reduced to zero, which is contrast to higher rates in large countries. These results indicate much more complexity of tax interactions among Asian countries in comparison with European ones. Generally, a successful tax reform involves a continuing political support and adequate administrative follow-up.

The role of the Vietnamese government has changed because of the shift from a centrally- planned mechanism to a market economy. In an open economy, the tax system should raise adequate revenue and minimize distortions. Moreover, tax policy should 
follow regional and global trends to facilitate tax compliance of the rapidly growing private sector. The cornerstones of this reform is WTO accession which requires legal completion: moving from high-income taxation to a universal income tax, and the adoption of a natural resources tax law to ensure social equality and efficiency in exploiting and using the natural resources. Meanwhile, the administration of the tax system should be strengthened. However, tax policy reform still faces major tasks: further simplifying the VAT system; addressing newly emerging challenges in the direct taxation such as cross-border trade, tax evasion, transfer pricing, and e-commerce transactions; and protecting the environment.

\subsection{Empirical model}

Tax reforms are to create an effective tax system, which is fundamental for successful development. As a result, tax reforms contribute to extending taxation capacity. The potential sources of tax revenue influences the taxable capacity. A simple mean of assessing taxable capacity is to relate tax revenue to GDP by using a regression model with explanatory variables that represent different elements of taxable capacity (Le et al., 2008). In this study, following Bird et al. (2004), we apply the empirical approach to both tax and total fiscal revenue efforts to test the robustness. The basic specification is:

$T A X_{t}=f\left(G D P_{t}, T R A D E_{t}, A G R_{t}, P O P_{t}\right)$

Where:

TAX: Tax revenue ratio to GDP;

GDP: GDP per capita;

TRADE: Term of trade, measured as ratio of exports/imports of goods;

AGR: Agricultural added value; and

POP: Rate of population growth.

The underlying hypothesis of the specification is that the tax capacity is determined by economic factors and demographic characteristics. Major sets of the independent variables tested consist of traditional supply-side factors, including GDP per capita, population growth rate, international trade, and agricultural added value as a fraction of GDP. Table 1 describes statistics of variables in the equation (1). Data is collected from ADB (2014). 
GDP per capita (GDP): This variable is a proxy for the level of economic development. In our analysis, GDP per capita is measured in GDP at constant 2005 US dollar. As a higher level of income typically correlates with a greater demand for public goods and services, and higher income increases the overall ability to pay in a society, one should expect higher tax payment and collection (Fox \& Gurley, 2005). It is expected that the sign of the coefficient of GDP per capita in the regression is positive.

Trade openness (TRADE): This variable is an aggregated level of export plus import to GDP. Trade taxes have been one of the key sources of revenue in the developing world. We expect to observe a positive relationship between trade openness and taxable capacity, but the strength of this correlation should be gradually decreased (Rodrik, 1996).

Agricultural value (AGR): Agricultural value is measured as a share in GDP. Agriculture is a hard-to-tax sector. Vietnamese government exempts from taxes a large share of agricultural activities due to its inherent difficulty in collecting the tax or due to equity and political reasons. Thus, a higher level of agricultural added value is expected to correlate with a lower level of taxable capacity (Le et al., 2008).

Population growth rate (POP): To test the impact of demographic characteristics on a country's taxable income, we use population growth rate. Bird et al. (2004) explain that when population growth rate increases, the tax system may lag behind in its ability to catch up new taxpayers. This problem lies in when a country has weak tax administration capacity. Hence, the population growth rate is expected to be negatively related to the tax capacity (Bird et al., 2004; Le et al., 2008).

Raising revenue is probably much more difficult due to limited revenue sources. Moreover, increasing tax revenue may hinder economic growth. Numerous studies have investigated the empirical relationship between tax and growth. Barro (1991) and King and Rebelo (1990) suggest that a growth in tax volume leads to a reduction in growth while Kneller, Bleaney, and Gemmell (1999) report a non-significant or even positive correlation between the two. Tosun and Abizadeh (2005) find that economic growth, measured by GDP per capita, has a significant effect on the tax mix of OECD countries. Mendoza, Razin, and Tesar (1994) conclude that tax mix has no significant effect on growth.

In this study, we use Johansen method to test for cointegration between tax revenue and economic growth given by equation (2): 


$$
G D P_{t}=\alpha+\varphi T A X_{t}+\varepsilon
$$

This technique allows us to test whether tax revenue (TAX) enhances economic growth (GDP) or not. If the null hypothesis of no-cointegration between GDP and TAX is not rejected, it implies that the tax policy is not effective. However, in case the null hypothesis is rejected with $\varphi>0$, the tax policy is effective. Nonetheless, if $\varphi<0$, the policy might be not effective once tax revenue growth is detrimental to economic growth.

\section{The situation of tax reforms in Vietnam}

The previous socioeconomic state establishes perquisites for the next phase of the tax reform. Since economic reform in 1986, called "Doi Moi", the Vietnam tax system has gone through three fundamental phases to improve its competitiveness. The first phase of reform was implemented in the early 1990s with the introduction of a unified tax system applied to both private and public sectors. The second phase of reform was initiated in the late 1990s due to ASEAN Trade Freedom Agreement (AFTA) and preparation for WTO accession with the introduction of value-added tax and corporate income tax. According to Decision 201/2004/QD-TTg, the third phase of tax reform program till 2010 was implemented to simplify the tax system and modernize the tax administration. As a result, tax becomes the main revenue source of the national budget, and a tool for government to manage and adjust the economy at the macro level. The tax revenue as percentage of GDP rose from 11\% in 1990 to $19 \%$ in 2000 and over $20 \%$ in 2012.

\subsection{Determinants of taxation capacity}

Table 1 provides definitions and descriptive statistics of variables in our growth regression. Data used in this paper are annual figures covering the period 1988-2013, collected from ADB (ADB, 2014). Tax revenue (TAX) includes direct and indirect revenue as a share in GDP (\%). The growth rate (GDP) is computed as the first difference of $\log$ (GDP-capita). Trade openness (TRADE) is export value plus import value as a share in GDP (\%). Agriculture value (AGR) is as a share in GDP (\%). Besides, the population growth is the first difference of $\log$ (population). 


\section{Table 1}

Descriptive statistics of variables

\begin{tabular}{lllllll}
\hline Variable & Definition & Obs & Mean & Std. Dev. & Min & Max \\
\hline TAX & Tax revenue/GDP (\%) & 26 & 17.760 & 4.629 & 2.950 & 22.463 \\
GDP & dlog of GDP_capita (\%) & 25 & .062 & .32135 & -1.419 & .377 \\
TRADE & $\begin{array}{l}\text { Export value plus Import } \\
\text { value as a share in GDP (\%) }\end{array}$ & 26 & 91.272 & 37.921 & 8.436 & 149.976 \\
& Agriculture value as a share & 26 & 26.122 & 7.970 & 18.379 & 46.297 \\
AGR & in GDP (\%) & & & & & \\
\multirow{2}{*}{ POP } & dlog of population (\%) & 25 & -7.70 & 772 & -8.88 & -6.33 \\
\hline
\end{tabular}

Source: Authors calculate from ADB data (2014).

Prior to the estimate of the equation (1), stationary test of variables is conducted. All these variables are non-trend stationary at level (0) with significance levels of $1 \%$ and $5 \%$. The empirical results are presented in Table 2 for taxable capacity. In Table 2 coefficients on the entire set of independent variables generally bear expected signs and are statistically significant. Results of Ramsey, heteroskedasticity, and multicollinearity tests show that the empirical model is appropriate. The exception is the coefficients on POP, which does not have the expected sign. This finding means that an increased population growth rate may lead to an increased aggregate demand. As a result, tax base is expanded and taxation capacity is higher. In general, the results support previous studies of determinants of taxable capacity such as empirical works by Bird et al. (2007), and Le et al. (2008).

The results obtained from the regression analysis suggest that among the explanatory variables, GDP growth, share of agriculture in GDP, and international trade openness have significant impacts on tax revenue potential in Vietnam. These results suggest that tax policy should create a supportive environment for economic growth, international integration and the change in GDP structure in order to consolidate the sustainability of tax revenue resources. 


\section{Table 2}

Estimated results of taxable capacity

(Dependent variable: Tax revenue/GDP)

\begin{tabular}{|c|c|c|c|c|c|c|}
\hline Variables & Coef. & Std. Err. & $\mathrm{t}$ & $\mathrm{P}>\mathrm{t}$ & [95\% Conf. & Interval] \\
\hline GDP & .270 & .096 & 2.79 & $0.011 * *$ & .068 & .472 \\
\hline TRADE & .202 & .092 & 2.17 & $0.042 * *$ & .008 & .395 \\
\hline AGR & -.041 & .004 & -8.98 & $0.000 * * *$ & -.051 & -.031 \\
\hline POP & 1.06 & 3.93 & 2.69 & $0.014 * *$ & 2.37 & 1.87 \\
\hline Cons & 4.709 & .412 & 11.42 & $0.000 * * *$ & 3.849 & 5.568 \\
\hline \multirow[t]{2}{*}{ Number of obs } & \multicolumn{6}{|c|}{25} \\
\hline & \multicolumn{6}{|c|}{$F(4,20)=96.63$ Prob $>F=0.0000$} \\
\hline R-squared & \multicolumn{6}{|c|}{0.9508} \\
\hline Adj R-squared & \multicolumn{6}{|c|}{0.9410} \\
\hline Ramsey reset test & \multicolumn{6}{|c|}{$F(3,17)=0.29 ;$ Prob $>F=0.8339$} \\
\hline $\begin{array}{l}\text { Breusch-Pagan test for } \\
\text { heteroskedasticity }\end{array}$ & \multicolumn{6}{|c|}{$\operatorname{chi} 2(1)=1.16 ;$ Prob $>\operatorname{chi} 2=0.2805$} \\
\hline Multicollinearity test & \multicolumn{6}{|c|}{ Mean VIF $7.71<10$} \\
\hline
\end{tabular}

Note: $* *$ and $* * *$ denote significance levels of $5 \%$ and $1 \%$ respectively.

\subsection{Current tax structure in Vietnam and regional comparison}

\subsubsection{Value-added tax (VAT)}

The current VAT law has three applicable tax rates: $0 \%, 5 \%$, and $10 \%$. Similar to the 1999 VAT Law, zero rate is applied to goods and services traded across borders, 26 goods and services are exempt from this tax net, while the five-percent rate is applied to 15 categories of goods and services. The standard rate still remains at $10 \%$. Different from the 1999 VAT Law, the rate of $20 \%$ applied to five groups of goods - precious metal, hotel tourism, lottery, shipping and brokerage service - is eliminated.

There is a mix in applying VAT rates in ASEAN. Among many ASEAN countries where a single VAT is applied, Vietnam and Indonesia used reduced rates along with standard rates. Some countries such as Malaysia, Myanmar, and Singapore apply the 
goods and services tax or GST. There is no VAT regime or the like in Brunei. However, the multiplicity of VAT rates not only makes it difficult for tax officers to collect tax but also creates opportunities for taxpayers to reduce their tax liability. Moreover, the differences in VAT regimes among many ASEAN members impose a major challenge for tax harmonization.

\subsubsection{Corporate income tax (CIT)}

Compared to the profit tax introduced in 1990, the 1999 Corporate Income Tax Law has a narrower coverage and more exemptions. Since its introduction in 1999, the CIT has been amended several times in order to build a business-friendly environment. The current CIT law enacted in 2009 does not make any distinction between enterprises of different sectors.

There are several features of the existing CIT: (1) tax base that includes capital gains; (2) deduction regulations that put limit on many types of expenditures such as advertising; (3) the standard rate of 22\%; (4) oil, gas, and other precious materials are taxed at higher rates, varying between $32 \%$ and 50\%; and (5) tax incentives including preferential or reduced rates, outright tax exemption or a tax holiday, and accelerated depreciation applied to specific projects. The current tax base is considered as relatively small since most developed countries tax incomes from all sources regardless of whether they are from business, trade, and non-business activities.

The average tax rates around the world are fall in the range of $20 \%$ to $40 \%$, in which Europe is at the low of 20.6\%. Since signing the AEC Blueprint in 2007, a declining trend in the CIT has been seen in the ASEAN region. It is likely that the CIT rate in the region will converge at $20 \%$ with the exception of Singapore where the lowest CIT rate of $17 \%$ is in place.

\subsubsection{Personal income tax (PIT)}

The 2009 Law on Personal Income Tax has seven tax brackets: 5, 10, 15, 20, 25, 30, and 35 percent. Compared to the 2007 Ordinance of Income Tax on High Income Earners, the 2009 PIT Law has: (1) expanded the tax base by removing distinction between Vietnamese nationals and foreigners or between regular and irregular income and eliminated most of tax-free and job-related allowances; and (2) reduced cases of tax exemption. 
Generally, many ASEAN members have reduced their PIT rates after signing the AEC Blueprint. Since 2007, Vietnam, Indonesia, Malaysia, and Thailand have started reducing the top marginal PIT rates from the high of 40, 35, 28, and 37 percent to 35, 30, 26, and 35 percent, respectively. Philippines still keeps its PIT rates unchanged at $32 \%$ while Singapore is still at the lowest PIT rate of $20 \%$. The PIT rates of ASEAN state members seem quietly diverged. In the absence of tax harmonization, ASEAN nations can manipulate the PIT rates to compete with their neighbors.

\subsubsection{Excise or Special Consumption Tax (SCT)}

Goods and services considered as socially and environmentally undesirable and luxury goods are subjected to SCT with tax rates ranging from $10 \%$ to $65 \%$. SCT rates on gasoline and golf service are only $10 \%$ and $15 \%$ respectively, which are relatively low in comparison with those on other goods and services such as playing cards and votive objects. Currently, the ten-percent SCT rate on gasoline is acceptable due to the pressure of global price of oil and inflation. However, in the long run, the rates must be raised up to those levels in line with other countries.

The excise tax is a critical issue for ASEAN countries as the AEC is established in 2015. Harmonization of excise tax needs to be discussed thoroughly. Excise tax is named differently by ASEAN countries: "Special Consumption Tax" in Vietnam, "Luxury Sales Tax" in Indonesia, and a "Liquor Tax" and a "Tobacco Tax" in Thailand. Generally speaking, five commodities - tobacco, wine, vehicle, distilled spirits, and beer - are subjected to the excise tax net in all countries. Other commodities are only taxed in some countries. For instance, non-alcoholic beverages are subjected to the excise tax in Cambodia, Laos PDR, Malaysia, and Thailand, but they are free from this tax in Vietnam.

\subsubsection{Export-Import Tax or Trade Tax}

All cross-border trades are subjected to the export-import tax or trade tax. One factor that determines the tax applied to imported goods is country of origin: (1) goods from countries with MFN status are subjected to preferential rates, (2) goods from countries with special trade agreements with Vietnam enjoy special preferential tariff rates, and (3) goods from other countries are assigned standard rates. The other determinant of the tariff rate is classification of goods: (1) inputs enjoy the lowest rates; (2) intermediate goods are subjected to the next higher tax rates; and (3) pure consumption goods are taxed at the highest rates. 
The international norms for cross-border trade are established by WTO. The main concern after joining WTO and signing the AEC Blueprint is the reduction in tariff and custom duties. By its very nature, reduction or removal of tariff and custom duties is inevitable upon engagement in any free trade agreement. As required by the AEC Blueprint and CEPT AFTA, all import duties should be eliminated by 2010 for the ASEAN-6 group and by 2015 for the CVLM group (including Vietnam). The unprocessed agricultural products are in Sensitive and Highly Sensitive Lists and state members are offered longer times to remove the tariff, but this delay will not last long. Consequently, the question now is whether or not revenues loss caused by reduction and removal of tariff and customs duties is offset by increased trade and expenditures caused by free trade. Therefore, a shift to taxing on expenditures and sales is of major importance.

\subsubsection{Tax on Natural Resources}

Achieving the sustainability of economic development and growth is important because it prevents overuse of the natural resources. Moreover, natural resources taxation plays a more important role in maintaining the tax revenue when other taxes such as tariff and CIT are reducing. Moreover, natural resources taxation makes a greater contribution in case of increasing oil export and environmental pollutions in recent years. The royalty rates take a wide range, from $1 \%$ to the high of $40 \%$.

The natural resources are divided into four categories: minerals, natural forest products, natural aquatic resources and natural water, and oil and natural gas. Minerals, both metallic and nonmetallic ones, are subjected to rates ranging from 5\% to $30 \%$. The range for most natural forest products is between $10 \%$ to $30 \%$. Among many types of natural resources, royalty rates on crude oil could reach the highest rate of $40 \%$. Most items in the category of natural aquatic resources and natural water are taxed at a much lower royalty rates, varying between $1 \%$ and $10 \%$. Among the four categories, minerals are subjected to royalty alone while oil and natural gas are double taxed. Apart from royalties, oil and natural gas are taxed at the firm level.

\subsubsection{Tax administration reform}

The tax administration is also modernized to match the new tax regulations. The Tax Administration Law adopted in 2006 is expected to enhance the transparency and integrity of the General Department of Taxation. It provides the legal framework for 
ensuring the tax compliance of the robust private sector and preventing power abuse by tax officials.

Some remarkable features of this law are: (1) well-defined responsibility of taxpayers, tax agencies, and other relevant organizations; (2) taxpayers are provided with a unique taxpayer identification number; (3) equitable treatment for tax payment and tax refund; and (4) guides for using the third-party information to enhance the audit and law enforcement. These changes help improve the simplicity and efficiency in the process of tax monitoring and tax collecting.

Moreover, the TAMP (Tax Administration Modernization Project) applied as from 2007 is a prerequisite for realizing long-term objectives of the Tax Administration Law. The priority of this project is to develop the information system that could improve tax collection and tax enforcement in Vietnam.

\section{Challenges to tax reform in Vietnam}

\subsection{Tax revenue and economic growth}

Does tax revenue (TAX) enhance economic growth (GDP)? Empirically, we conduct tests to investigate whether there is a long-run equilibrium relationship between real GDP growth and tax revenues growth in Vietnam by using Johansen technique for cointegration. Table 1 shows descriptive statistics of these variables. The Augmented Dickey-Fuller (ADF) Unit Root tests are employed to test the integration level and the possible long-run relationship between GDP growth and tax revenues growth. Those two variables are stationary at level, $\mathrm{I}(0)$ with significance level of $1 \%$. ADF tests reveal that these variables are stationary at level, that is, they are integrated at order zero, I(0). The cointegration test results demonstrate that the null hypothesis is rejected at the fivepercent level (see Table 3). The cointegration equation estimated by the cointegrating vector: $G D P_{t}=0.501-0.206^{*} T A X_{t}$. Since $\varphi<0$, it implies that tax revenue growth hinders economic growth. 


\section{Table 3}

Johansen tests for cointegration

\begin{tabular}{ccccc}
\hline Maximum rank & Likelihood & Eigenvalue & Trace statistic & Critical value 5\% \\
\hline 0 & 50.102 & & 36.624 & 15.41 \\
1 & 61.411 & 0.610 & 14.006 & 3.76 \\
2 & 68.414 & 0.442 & & \\
Johansen normalization restriction imposed & & & \\
beta & Coef. & Std. Err. & $\mathrm{Z}$ & \\
GDP & 1 & & & \\
TAX & -.206 & .069 & -2.99 & 0.003 \\
cons & .501 & & \\
\hline
\end{tabular}

To reinforce the above finding, relationship between economic growth (GDP) and tax revenue (TAX) is further examined by non-linear equation (3) with two control variables: ratio of budget deficit to GDP (BDEF) and Agricultural added value (AGR).

$$
G D P_{t}=\alpha_{t}+\beta_{1} T A X+\beta_{2} T A X^{2}+\beta_{3} B D E F+\beta_{4} A G R+\varepsilon_{t}
$$

The empirical results indicate coefficient of TAX2 (square of TAX) is negative and significant, which implies that there exists a non-linear relationship between economic growth and tax revenue size (see Table 4). Generally, raising tax revenue size does not support economic growth.

\section{Table 4}

Regression of economic growth and tax revenue

(Dependent variable: Economic growth)

\begin{tabular}{lllll}
\hline Variables & Coef. & Std. Err. & $\mathrm{t}$ & $\mathrm{P}>\mathrm{t}$ \\
\hline TAX & .019 & .006 & 3.03 & $0.007 * *$ \\
TAX2 & -.0003 & .0001 & -2.46 & $0.023 * *$ \\
BDEF & .0006 & .001 & 0.56 & 0.579 \\
AGR & .003 & .001 & 3.50 & $0.002 * *$ \\
cons & -.237 & .089 & -2.65 & $0.015 * *$
\end{tabular}




\begin{tabular}{llll}
\hline Variables & Coef. & Std. Err. & t \\
\hline Adj R-squared & 0.3693 & \\
Ramsey RESET & Prob $>\mathrm{F}=0.2698$ & \\
Breusch-Pagan test for heteroskedasticity & Prob $>$ chi2 $=0.6844$ & \\
\hline
\end{tabular}

Note: $* *$ denotes level of significance at $5 \%$.

\subsection{Limits of tax administration in Vietnam}

Because empirical evidence indicates that tax increases hinder economic growth, tax reform should be designed carefully in order not to hinder private investment. Firms in many countries take advantage of the complexity and ambiguity of the tax laws to lower their tax liability. This problem becomes more serious in developing countries where tax administration is ineffective and unaccountable. Theoretically, tax leakage is caused by: (1) tax evasion in which taxpayers try to hide part of their true tax liability; and (2) tax avoidance in which taxpayers take advantage of the loopholes in the existing tax laws to lower their tax liability.

The cost of tax compliance includes expenses needed for tax planning and related paper works. Compared to their counterparts in other countries, companies in Vietnam have to spend more time complying with the tax regulations. The Doing Business Report prepared by World Bank provides "paying taxes" ranking of many countries. Accordingly, a business operated in Vietnam needs 872 hours to interact with the tax officials and tax agencies while the figures in Thailand, Indonesia, and Singapore are 264, 259, and 82 hours respectively. Moreover, firms active in Vietnam have to pay taxes 32 times a year, which is relatively high as compared to the figure five times in Singapore.

Vietnam's ranking in paying taxes appears to be unchanged during the period 20072013 although many changes took place in the tax system and tax administration. Tax administration of Vietnam is inefficient because of high collection cost, corruption, and low compliance. The complexity of tax laws, the high discretionary powers of tax officials, and the low cost of punishment are factors that create opportunities for corruption in tax administration.

High corruption is a severe problem for ASEAN countries. As reported by Transparency International, over the period 2006-2011, most ASEAN countries have 
the Corruption Perception Index (CPIx) larger than two and their ranking is about 100 out of 164. The CPIx of Vietnam is at a standstill, from 112 in 2006 to 111 in 2011. Consequently, negotiating with tax officials is an essential part of doing business in Vietnam. Small and medium enterprises are vulnerable to corrupt tax officials.

In a nutshell, the challenges are not in the declining tax revenue but at how the tax leakage and the cost of tax compliance are addressed. In other words, the tax administration should be modernized and simplified so that individuals and businesses find it inexpensive to obey tax laws, which helps attract more capital. Other shortcomings of tax administration are: (1) responsibilities of the General Department of Taxation, provincial offices, and district offices are not clarified; and (2) the legal framework for the cooperation between relevant institutions such as tax and custom agencies is not in place.

\subsection{Tax Competition and harmonization in ASEAN}

Since 1997 the economic integration in ASEAN is boosted with many agreements such as free trade agreements (FTAs), mutual agreement procedures (MAP) and advanced pricing agreements (APA), ASEAN Free Trade Area (AFTA), and Common Effective Preferential Tariff (CEPT). Economic integration requires tax reform and tax harmonization; however, this process is adversely affected by legal, institutional, and cultural barriers. Velayos, Barreix, and Villela (2008) suggest several levels of tax harmonization which are important for ASEAN.

4.3.1. Convergence level

AFTA and several other large intra-regional trade agreements are examples of regional liberalization in trade and financial systems. These agreements call for efficient, non-discriminatory, and convergent tax systems. Vietnam and other ASEAN countries have undergone increasing pressure to make tax system more integrated.

Transfer pricing policy, an example of convergence in Velayos et al. (2008), is a major concern in Vietnam. Transfer pricing regulations were introduced in 2006, but they seemed to be inefficient. As with mutual agreement procedures (MAP) and advanced pricing agreements (APA) taking effect in early 2013, the Vietnam transfer pricing regime became more comprehensive. 
In terms of free trade agreements, there have been many movements toward tax convergence level in Vietnam: signing eight FTAs and negotiating seven others. The FTAs would have a huge effect on Vietnamese businesses: fierce competition, increasing cross-border trade, and trade deficit caused by tariff reductions. Moreover, Vietnam has to simplify its legal system according to international commitments (Chirathivat \& Srisangnam, 2013).

\subsubsection{Cooperation level}

Cooperation in ASEAN taxation is necessary to improve double taxation treaty coverage, address tax avoidance, and design corporate taxation. It is likely that bilateral agreements on avoidance of double taxation between member countries are not completed as AEC Blueprint predicted. Vietnam and Indonesia are highly cross-linked in tax matters, while others are not at all. In fact, ASEAN countries tend to establish the relation with non-ASEAN countries (Büttner et al., 2013). Intra-ASEAN cooperation depends on bargaining power of ASEAN countries. In the long run, there should be a broader cooperation between ASEAN members with respect to taxation. A forum for dialogue, exchange and peer learning as well as opportunities for education and training in tax matters are all necessary.

4.3.3. Coordination level, compatibility level, and standardization level

This higher kind of tax harmonization may be unclearly expressed in ASEAN community. Currently, only the ASEAN-6 group (comprising Brunei, Indonesia, Malaysia, Philippines, Singapore, and Thailand) has fully ratified the tariff reduction. These countries have reduced tariff on products in the CEPT Inclusion List to the 0-5 percent range (Chirathivat \& Srisangnam, 2013). Other countries (Cambodia, Lao PDR, Myanmar, and Vietnam) are on the process to reduce their tariffs. This practice implies that standardization cannot occur in a short run. ASEAN countries should harmonize not only the customs duties, but also the systems of VAT and excise duties. The existing Double Taxation Agreement treaty network needs to be completed.

\section{Conclusions and recommendations}

\subsection{Conclusions}

After over 20 years of tax reform, taxation capacity was improved. Raising tax revenue is comparable to economic and structural potentials of tax system. The tax 
revenue rose and positively contributed to fiscal balance. The tax system was modernized and relatively appropriate to the international common practices. Tax structure in Vietnam changed from relying mostly on production and trade taxes to a greater reliance on taxes on consumption. In the context of economic ups and downs, this may be a reasonable solution. Indirect taxes are more stable as revenue resources. The taxes on international trade (tariffs) and corporate income decrease whereas VAT rises sharply. These are less distorting than production taxes. Growth-friendly approach is the primary driver for this change.

Taxation capacity of tax system in Vietnam is dominated by economic factors. Higher income level, more trade openness, and lower agriculture share in GDP are likely to lead to a higher tax and revenue capacity. However, there are major challenges of tax system in Vietnam. Firstly, the empirical results show that raising tax revenue size is of no benefit to economic growth. The target of tax revenue of $23-24 \%$ of GDP by 2020 could be considered quite ambitious. Vietnam's tax revenue average as a share in GDP is of the highest in ASEAN and the world. Chances to raise revenue seem very slim because many revenue sources are unsustainable and may slump or disappear in the coming years, especially trade taxes.

Secondly, tax administrative reform in Vietnam has poor rankings. Corruption in tax sector is another challenge that makes it difficult to enforce tax laws. Finally, weak cooperation between ASEAN members is another obstacle for future tax reform in Vietnam. Economic integration requires changes in taxation policy and calls for greater tax harmonization in the ASEAN bloc, but legal, institutional, and cultural barriers adversely affect attitudes toward changes in the tax system. This can make Vietnam lag farther behind in modernization and international integration.

\subsection{Some recommendations}

The Vietnamese government vision is that by 2020 the country will have become an industrial nation. This is achievable. However, a number of things need improvement from now till then to crystallize this vision. One of them is undoubtedly the state of the current tax system where tax reform is necessary.

Firstly, reform of tax structure will create a broad based tax system where even low tax rates can help the government increase the tax revenue appropriately. Remark by Giannopoulos (2009) about the Malaysian government is also true in Vietnam: "Growing trade liberalization and the resulting decline on the reliance on trade taxes, 
such as import duties, is putting further downwards pressure on tax revenue. The Malaysian government is under extreme competition for that foreign direct investment dollar to assist in our development (...). This is putting further downwards pressure on tax revenues, compounded by a slowing economy and lower company profits."

For this reason, in tax structure, indirect taxes should be higher than direct taxes in order to create friendly conditions for investment, business, and sustainable tax revenue. And some main taxes should be adjusted. VAT should gradually be reformed until a single tax rate could be applied by 2020 . The special consumption tax on tobacco, beer, liquor, and automobiles should be reduced to ensure stability of the domestic market and international integration. Export taxes should be restructured to encourage production of high value-added exports while restraining export of raw materials and minerals. Import taxes should be reduced, with the number of tax levels limited and trade barriers removed to meet international commitments. Corporate income taxes should also be restructured to support companies to enforce their capital and production and sharpen their competition. Personal income taxes should be based on a more comprehensive basis.

Secondly, tax administration should also be modernized in light of international standards, with simpler administrative procedures. The tax revenue, to a large extent, depends on the effectiveness of the tax administration (Mansor \& Tayib, 2012). Corruption, compliance and administrative costs could be reduced substantially when the taxes are well administered (James, 2012). The performance of tax administration could be improved by promoting such efforts as: (1) law enforcements, (2) engagement or cooperation between tax offices and other institutions, (3) operation of the tax agencies, and (4) regional cooperation:

(1) Enforcement of the tax laws plays an important role in any tax reform. The tax reform will go nowhere unless what are written into laws are brought into force by authorities. The three principles of the tax law enforcement are simplicity, transparency, and accountability.

First, simplicity is the primary principle of any tax system, which focuses on the convenience of taxpayers in complying with tax laws. The simplicity of tax system requires that: (i) the tax base must be expanded whereas lowering the overall rate of taxation on each unit of goods or on income; and (ii) tax management must be simplified, which is based on three major pillars, namely simplified administrative procedures, qualified human resources, and highly integrated automatic taxation information. 
Second, transparency and accountability usually go hand in hand. Transparency refers to the clarity of tax regulations and tax administration while accountability involves the responsibilities of the tax offices to provide answers about their actions to many stakeholders such as the public and media.

To build a more responsive and more accountable tax system, the General Department of Taxation should improve its website to make it easier for taxpayers to access necessary information or file complaints. Moreover, the process of designing tax laws should follow a primary principle so that stakeholders can monitor the consistency of the tax laws. Furthermore, the government needs to enhance its supervision; deal with illegal activities; and fight against smuggling, trade frauds, market manipulation, and unfair competition practices while providing favorable conditions for all economic activities. Detecting and strictly dealing with tax officers and civil servants as well as taxpayers who violate tax regulations are also necessary.

(2) Engagement implies that the involvement of the tax offices and other institutions is essential to ensuring the tax compliance by businesses and individuals. The current high level of tax incompliance persists because the taxpayers find many opportunities and loopholes in the tax system to avoid a large proportion of their tax liabilities. The cooperation among many players in the tax system not only eliminates opportunities for tax incompliance but also increases the efficiency of the tax administration. The engagement of other institutions, such as banks, could make it easier for tax officers to collect tax payments. The authorities should consider the trade-off between equity and efficiency of the tax law, and remember that tax exemptions only exist where the cost of compliance is less than the equity consideration.

(3) The operation of the tax agencies could affect the willingness of the taxpayers to comply with the laws (James, 2012). Vietnam has to develop information technology in various functions such as tax declaration, tax collection, and information inquiry. Besides technology, tax officers and other staff need to be trained so that they know how to treat and assist taxpayers in a proper manner. Moreover, it is necessary to further streamline procedures and shorten the time required in all steps. To take some examples, starting new businesses needs no more than six days; and time required of businesses to complete tax payment procedures should equal the average time allowed by the ASEAN6 group (171 hours/year). 
(4) The long-term need is to harmonize tax system grounds such as tax incentive policies, VAT systems, and excise duties, etc. Vietnam and ASEAN countries should consistently and effectively implement international trade commitments

\section{References}

Ahmad, E., \& Stern, N. (1991). The theory and practice of tax reform in developing countries. Cambridge, UK: Cambridge University Press.

Asian Development Bank. (2014). Key Indicators for Asia and the Pacific 2014. Retrieved from http://www.adb.org/publications/key-indicators-asia-and-pacific-2014

Auerbach, A. (2010). Directions in tax and transfer theory. In Melbourne Institute - Australia's future tax and transfer policy conference (full report) (pp. 63-71). Melbourne, Australia: Melbourne Institute of Applied Economic and Social Research.

Barro, R. J. (1991). Economic growth in a cross-section of countries. Quarterly Journal of Economics, 106, 407-441.

Bird, R. M., Martinez-Vazquez, J., \& Torgler, B. (2004). Societal institutions and tax effort in developing countries (International Studies Program Working Paper 04-06). Atlanta, Georgia: Andrew Young School of Policy Studies, Georgia State University.

Bird, R., \& Gendron, P.P. (2007). The VAT in developing and transitional countries. Cambridge, UK: Cambridge University Press.

Bovenberg, L., Cnossen, S., \& Mooij, R. D. (2003). Introduction: Tax coordination in the European Union. International Tax and Public Finance, 10(6), 619-624.

Brys, B., Matthews, S., Herd, R., \& Wang, X. (2013). Tax policy and tax reform in the People's Republic of China (OECD Taxation Working Papers No 18). Paris, France: OECD Publishing.

Büttner, W., \& Associates (2013). Mapping taxation in selected Asian developing countries. Bonn, Germany: Deutsche Gesellschaft für Internationale Zusammenarbeit.

Chirathivat, S., \& Srisangnam, P. (2013). The 2030 architecture of Association of Southeast Asian Nations free trade agreements (ADBI Working Paper 419). Tokyo, Japan: Asian Development Bank Institute.

Diamond, P. A., \& Mirrlees, J. A. (1971a). Optimal taxation and public production I: Production efficiency. American Economic Review, 61(1), 8-27.

Diamond, P. A., \& Mirrlees, J. A. (1971b). Optimal taxation and public production II: Tax rules. American Economic Review, 61(3), 261-278.

Fox, W. F., \& Gurley, T. (2005). An exploration of tax patterns around the world. Tax Notes International: Special Reports, 37(9), 793-807. 
Giannopoulos, N. (2009, August 5). 101 things to be done before 2020: Tax reform. Borneo Post. Retrieved from http://www.swinburne.edu.my/media/campus_beyond/2009/beyond_details090805.htm

Harberger, A. C. (1962). The incidence of the corporation income tax. The Journal of Political Economy, 70(3), 215-240.

Ikhsan, M., Trialdi, L., \& Syahrial., S. (2005). Indonesia's new tax reform: Potential and direction. Journal of Asian Economics, 16(6), 1029-1046.

James, S. (2012). Behavioural economics and the risks of tax administration. eJournal of Tax Research, 10(2), 345-363.

Kim, J. (2005). Tax reform issues in Korea. Journal of Asian Economics, 16, 973-992.

King, R. G., \& Rebelo, S. (1990). Public policy and economic growth: Developing neoclassical implications. Journal of Political Economics, 98(5), S126-S150.

Kneller, R., Bleaney, M. F., \& Gemmell, N. (1999). Fiscal policy and growth: Evidence from OECD countries. Journal of Public Economics, 74(2), 171-190.

Le, T. M., Moreno-Dodson, B., \& Rojchaichaninthorn, J. (2008). Expanding taxable capacity and reaching revenue potential: Cross-country analysis. Washington D.C.: The World Bank.

Lin, S. (2004). China's capital tax reforms in an open economy. Journal of Comparative Economics, $32,128-147$.

Mansor, M., \& Tayib, M. (2012). Tax administration performance management: Towards an integrated and open system approach. International Journal of Trade, Economics \& Finance, 3(2), $136-142$.

Mendoza, E. G., Razin, A., \& Tesar, L. L. (1994). Effective tax rates in marcoeconomics: Crosscountry estimates of tax rates on factor incomes and consumption. Journal of Monetary Economics, 34(3), 297-323.

Mendoza, E. G., \& Tesar, L. L. (2005). Why hasn't tax competition triggered a race to the bottom? Some quantitative lessons from the EU. Journal of Monetary Economics, 52(1), 163-204.

Mirrlees, J., \& Associates, (2012). The Mirrlees review: A proposal for systematic tax reform. National Tax Journal, 65(3), 655-684.

Mitchell, D. J. (2009). The Economics of tax competition - Harmonization vs. liberalization. Adam Smith Institue. Retrieved August 20, 2014 from www.adamsmith.org/sites/default/.../taxcompetition.pdf

Rao, M. G. (2000). Tax reform in India: Achievements and challenges. Asia Pacific Development Journal, 7(2), 59-74.

Rao, M. G. (2005). Tax system reform in India: Achievements and challenges ahead. Journal of Asian Economics, 16(6), 993-1011. 
Rodrik, D. (1996). Why do more open economies have bigger governments? (Working Paper 5537). Cambridge, MA: National Bureau of Economic Research.

Sujjapongse, S. (2005). Tax policy and reform in Asian countries: Thailand's perspective. Journal of Asian Economics, 16(6), 1012-1028.

Suzuki, M. (2014). Corporate effective tax rates in Asian countries. Japan and the World Economy, $29,1-17$.

Tanzi, V. (2008, February). Theory and practice of tax policy and reform in a globalizing era. Paper presented at the international symposium on Tax Reform in Globalization Era: World Trend and Japan's Choice. Tokyo, Japan.

The World Bank Group. (2014). Doing Business Report 2014 Regional Profile: East Asia and the Pacific (EAP). Retrieved from http://www.doingbusiness.org/reports/ /media/GIAWB/ Doing\%20Business/Documents/Profiles/Regional/DB2014/DB14-East-Asia-Pacific.pdf

Tosun, M. S., \& Sohrab, A. (2005). Economic growth and tax components: An analysis of tax changes in OECD. Applied Economics, 37(19), 2251-2263.

Vazquez, J. M. (2011). Taxation in Asia. Manila, the Philippines: Asian Development Bank.

Velayos, F., Barreix, A., \& Villela, L. (2008). Regional integration and tax harmonization: Issues and recent experiences. In V. Tanzi, A. Barreix, \& L. Villela (eds.), Taxation and Latin American integration (pp. 79-128). Cambridge, MA: Harvard University Press.

Vietnamese Government. (2004). Decision No. 201/2004/QD-TTg on approving the tax system reform program till 2010 (in Vietnamese). Retrieved from http://thuvienphapluat.vn/archive/ Quyet-dinh-201-2004-QD-TTg-chuong-trinh-cai-cach-he-thong-thue-den-2010-vb52604.aspx

Vietnamese Government. (2011). Decision No. 732/2011/QD-TTg on approving a 10-year tax system reform strategy in the 2011-2020 period (in Vietnamese). Retrieved from http://thuvienphapluat.vn/van-ban/Thue-Phi-Le-Phi/Quyet-dinh-732-QD-TTg-phe-duyet-Chienluoc-cai-cach-he-thong-thue-124157.aspx

Warburton, R., \& Hendy, P. (2006). International comparison of Australia's taxes. Canberra, Australia: The Treasury.

Wilson, J. D. (1987). Trade, capital mobility, and tax competition. Journal of Political Economy, 95(4), 835-856. 